\title{
Therapeutic Potential of Milk Whey
}

\author{
Charu Gupta * and Dhan Prakash
}

Amity Institute for Herbal Research and Studies, Amity University Uttar Pradesh, Sector-125, Noida-201313, India; dprakash_in@yahoo.com

* Correspondence: charumicro@gmail.com; Tel.: +91-120-439-2549

Academic Editor: Alessandra Durazzo

Received: 25 April 2017; Accepted: 27 June 2017; Published: 5 July 2017

\begin{abstract}
Milk whey-commonly known as cheese whey-is a by-product of cheese or casein in the dairy industry and contains usually high levels of lactose, low levels of nitrogenous compounds, protein, salts, lactic acid and small amounts of vitamins and minerals. Milk whey contains several unique components like immunoglobulins (Igs), lactoferrin (Lf), lactoperoxidase (Lp), glycomacropeptide (GMP) and sphingolipids that possess some important antimicrobial and antiviral properties. Some whey components possess anticancer properties such as sphingomyelin, which have the potential to inhibit colon cancer. Immunoglobulin-G (IgGs), Lp and Lf concentrated from whey participates in host immunity. IgGs binds with bacterial toxins and lowers the bacterial load in the large bowel. There are some whey-derived carbohydrate components that possess prebiotic activity. Lactose support lactic acid bacteria (such as Bifidobacteria and Lactobacilli). Stallic acids, an oligosaccharide in whey, are typically attached to proteins, and possess prebiotic properties. The uniqueness of whey proteins is due to their ability to boost the level of glutathione (GSH) in various tissues and also to optimize various processes of the immune system. The role of GSH is very critical as it protects the cells against free radical damage, infections, toxins, pollution and UV exposure. Overall GSH acts as a centerpiece of the body's antioxidant defense system. It has been widely observed that individuals suffering from cancer, HIV, chronic fatigue syndrome and many other immune-compromising conditions have very poor levels of glutathione. The sulphur-containing amino-acids (cysteine and methionine) are also found in high levels in whey protein. Thus, the present review will focus on the therapeutic potential of milk whey such as antibiotic, anti-cancer, anti-toxin, immune-enhancer, prebiotic property etc.
\end{abstract}

Keywords: milk whey; therapeutic potential; cheese whey; antimicrobial; immune-enhancer; bioactive peptides

\section{Introduction}

Whey is generally released as a by-product during cheese manufacturing. The typical composition of milk comprises about $3.6 \%$ protein, out of which casein predominates to around $80 \%$ and rest $20 \%$ are called as the whey proteins. Whey proteins are unique as they contain all the essential amino acids of good quality protein. Milk whey and whey proteins have different biological and functional properties. Consequently, milk whey proteins are used in the manufacture of various products such as infant foods, nutritional products for athletes, tailor made specialized products for controlling obesity, mood control and other clinical protein supplements such as for enteral disturbances. (Yalcin, 2006 [1]).

Bioactive peptides present in milk whey are one of the most studied compounds in different dairy products. Bioactive peptides from dairy sources are majorly classified on the basis of their biological roles as anti-hypertensive, anti-oxidative, immmuno-modulant, anti-mutagenic, anti-microbial, opioid, anti-thrombotic, anti-obesity and mineral-binding agents. These bioactive peptides are produced by enzymatic hydrolysis during fermentation and gastrointestinal digestion. Thus, fermented dairy 
products like yogurt, cheese and buttermilk are gaining popularity worldwide and are considered as an excellent source of dairy peptides. Furthermore, these dairy products are also associated with lower risks of hypertension, coagulopathy, stroke and cancer insurgences (Sultan et al., 2014 [2]).

\section{Historical Background}

Historically, whey was considered as a cure for all common ailments ranging from gastrointestinal complaints to joint and ligament problems.

Nanna Rognvaldardottir, a food expert from Iceland, described whey (also called syra in Iceland), as fermented liquid that is stored in barrels.

Before its consumption, Syra is diluted with water. It is also used as a marinade or preservative for meat and other food.

Syra was the most common beverage of Icelandic people and replaced ale due to the lack of grains in that region (Rognvaldardottir, 2001 [3]).

\section{Milk Whey Components}

The major components of milk whey of nutraceutical potential includes beta-lactoglobulin, alpha-lactalbumin, bovine serum albumin (BSA), lactoferrin (Lf), immunoglobulins (Igs), lactoperoxidase (Lp) enzymes, glycomacropeptides (GMP), lactose and minerals. The composition of the whey liquid also depends upon the source of milk e.g., whey derived from buttermilk contains more lipid sphingomyelin as compared to those derived from cheese. Whey is a popular dietary protein supplement that is well known to possess antimicrobial activity, immune modulation, improved muscle strength and body composition. Furthermore, whey is known to prevent cardiovascular disease and osteoporosis.

The nutrient content of milk whey types (sweet whey and whey permeate) is described in Appedix Table A1 and the whey characteristics are highlighted in Appedix Table A2.

\subsection{Beta-Lactoglobulin}

Beta-lactoglobulin comprises approximately half of the total protein content in bovine whey, while it is absent in human milk. It is a source of both essential and branched chain amino acids. A retinol binding protein (a carrier of small hydrophobic molecules including retinoic acid) is present within the beta-lactoglobulin structure. This protein, has an ability to modulate lymphatic responses (Gupta et al., 2012; Yolken et al., 1985 [4,5]). It also has the property to bind to hydrophobic ligands such as fatty acids.

Recently, Le Maux et al. demonstrated that beta-lactoglobulin acts as a carrier molecule that alters the bio-accessibility of linoleate and linoleic acid (Le Maux et al., 2012 [6]). It also provides resistance against gastric- and simulated duodenal digestions. It also serves as a potential carrier for delivering gastric labile hydrophobic drugs. Thus it has a great potential to serve as a realistic protein candidate for safe delivery and protection of $\mathrm{pH}$-sensitive drugs in the stomach (Mehraban et al., 2013 [7]).

\subsection{Alpha-Lactalbumin}

Alpha-lactalbumin is reported to be the second most important protein in whey quantitatively and it represents approx. $20 \%(w / w)$ of the total whey protein. It is completely synthesized in the mammary gland. It has significant anti-proliferative effects in human adenocarcinoma cell lines such as Caco-2 and HT-29 (Brück et al., 2014 [8]). It also kills tumour cells and has bactericidal effects in the upper respiratory systems and protective effects on gastric mucosa.

Alpha-lactalbumin plays a vital role in reducing the risk of some cancers as it constrains cell division (Ganjam et al., 1997 [9]). In yet another study, it has also been found effective in the treatment of cognitive declination. This is due to the high tryptophan content in alpha-lactalbumin, that increases the plasma tryptophan-large neutral amino acids ration (Markus et al., 2002 [10]). 


\subsection{Bovine Serum Albumin (BSA)}

Bovine serum albumin (BSA) is not produced in the mammary gland, but is secreted in milk after its passive leakage from the blood stream. The most important property of bovine serum albumin is its ability to bind to various ligands reversibly. It is the principal carrier of fatty acids and can bind to free fatty acids and other lipids as well as flavoring compounds (Huang et al., 2004 [11]). However, this property is impaired upon denaturation on heating. BSA also inhibits tumor growth due to the modulation of activities of the autocrine growth regulatory factors (Laursen et al., 1990 [12]).

BSA also binds to fatty acids stored in the human body; and thus it also participates in lipid synthesis (Choi et al., 2002 [13]). In addition, BSA possess antioxidant activities (Tong et al., 2000 [14]).

BSA is a source of all major essential amino acids, whose therapeutic potential is still largely unexplored.

\subsection{Lactoferrin ( $L f)$}

Lactoferrin is an iron-binding glycoprotein that is present in whey fraction of milk and colostrum. It is a non-enzymatic antioxidant and consists of approximately 689 amino acid residues (Pierce et al., 1991 [15]). The concentration of lactoferrin in human milk and colostrum is reported to be about $2 \mathrm{mg} / \mathrm{mL}$ and $7 \mathrm{mg} / \mathrm{mL}$, respectively, whereas in bovine milk and colostrum it is around $0.2 \mathrm{mg} / \mathrm{mL}$ and $1.5 \mathrm{mg} / \mathrm{mL}$, respectively (Levay et al., 1995 [16]). Lactoferrin is a pre-dominant component of whey protein in human breast milk.

Lactoferrin is also known to be an important host defense molecule and performs a range of physiological functions such as antimicrobial, antiviral, immuno-modulatory and antioxidant activity. It has been shown in several scientific studies that lactoferrin, if administered orally, exerts several beneficial health effects on humans and animals, including anti-infective, anti-cancer and anti-inflammatory effects. Thus, lactoferrin possess the potential to be used as a food additive (El-Loly and Mahfouz, 2011 [17]).

\subsection{Immunoglobulins (Igs)}

Immunoglobulins (Ig) are antibodies and chemically gamma-globulins. The whey fraction of milk contains a major amount of immunoglobulins, comprising approximately $10 \%-15 \%$ of total whey proteins. Numerous studies have proved the therapeutic potential of immunoglobulins. They are known to possess vital biological properties.

In an in vitro study, it was shown that bovine milk-derived IgG suppresses human lymphocyte proliferative response to $\mathrm{T}$ cells at concentrations as low as $0.3 \mathrm{mg} / \mathrm{mL}$ of IgG. It was further concluded that bovine milk IgG concentration varies between $0.6-0.9 \mathrm{mg} / \mathrm{mL}$ and therefore confer immunity that is transmitted to humans (El-Loly, 2007 [18]). Previous studies have shown that unpasteurized cow milk contain specific antibodies to human rotavirus, and against bacteria such as E. coli, Salmonella enteriditis, S. typhimurium, and Shigella flexneri (Losso et al., 1993 [19]).

Nowadays, commercial colostral whey-derived immunoglobulin preparations are widely available in the market that are marketed under the category of feed supplements and newborn farm animal substitutes (Scammell, 2001 [20]).

There are few studies that have reported that the efficacy of these non-specific immunoglobulin products in the prevention and treatment of gastrointestinal infections is variable in different animal studies (Garry et al., 1996 [21]).

However, Hilpert et al. [22] described the production of 'hyper-immune milk' by immunizing the cows with specific antibodies and to prepare a whey protein concentrate for protecting young animals from disease.

An increasing number of controlled clinical studies have shown that the oral administration of immune milk preparations containing high titers of specific antibodies can provide effective protection 
and, to some extent, may also have therapeutic value against gastrointestinal infections in humans (Korhonen et al., 2000; Lilius and Marnila, 2001 [23,24]).

\subsection{Lactoperoxidase (LPO) Enzymes}

Milk whey contains many types of enzymes, such as lactoperoxidase, hydrolases, transferases, lyases, proteases and lipases. Lactoperoxidase accounts for $0.25-0.5$ percent of total protein found in whey. Lactoperoxidase is an important enzyme present in the whey fraction of milk. It is the most abundant enzyme in whey following the curding process. It has the property to catalyze certain molecules, and reduction of hydrogen peroxide. This enzyme system catalyzes peroxidation of thiocyanate and some halides (such as iodine and bromium), which ultimately generates products that inhibit and/or kill a range of bacterial species. It is heat tolerant and therefore lactoperoxidase is not inactivated during the pasteurization process, thereby suggesting its stability as a preservative.

The biological significance of this enzyme is that it has a natural protection system against the invasion of microorganisms. Besides its antiviral effect, it protects animal cells against various damages and peroxidative effects (de Wit and Van Hooydonk, 1996 [25]).

Lactoperoxidase also provides defense system against pathogen microorganisms from the digestive system of neonatal babies. The LPO enzyme functions as a non-immune biological defense system of mammals and catalyzes the oxidation of the thiocyanate ion into the antibacterial hypothiocyanate (Reiter and Perraudin, 1991 [26]). In yet another study, the oral administration of lactoperoxidase attenuated pneumonia in influenza virus-infected mice suppressed the infiltration of inflammatory cells in the lungs (Shin et al., 2005 [27]).

Thus the major application of lactoperoxidase is a protective factor against infectious microbes.

\subsection{Glycomacropeptides (GMP)}

Glycomacropeptides are also known as Casein Macro-Peptide (CMP) and constitutes about $10 \%-15 \%$ of protein in whey. It is produced in whey due to the breakdown of casein by chymosin enzyme during cheese-making process. It contains large numbers of branched chain amino acids; but lacks the aromatic amino acids such as phenylalanine, tryptophan and tyrosine.

The other advantage is that it can be safely administered to patients suffering with phenylketonuria (PKU) as it lacks phenylalanine (Marshall, 2004 [28]).

The GMP inhibits gastric acid secretions and modifies the blood concentration of regulatory digestive peptides. It induces satiety as it induces the release of cholecystokinin but similar results were not observed in human-fed GMP (Gustafson et al., 2001 [29]). The other role of GMP is to inhibit the adhesion of cariogenic bacteria such as Streptococcus mutans, Sanguis and Sobrinus to oral surfaces and therefore can modify the composition of plaque bacteria to control its acid production and, in turn, reduce the demineralization of enamel and promote re-mineralization. The GMP is also a source of $\mathrm{N}$-acetyl-necromatic acid and its dietary intake can increase the sialic acid content of saliva that effects its viscosity and protective function (Gupta et al., 2012 [4]).

\subsection{Lysozyme (N-Acetylmuramide Glycan-Hydrolase)}

Lysozyme is a hydrolytic enzyme that is widely distributed in nature and occurs in many body fluids and tissues of living organisms (Fox and Kelly, 2006 [30]). Although the highest concentration of the enzyme is found in tears and egg white protein, but is also present in human milk. It exhibits antibacterial activity only against gram-positive bacteria.

This enzyme has wider industrial applications as a food additive, in medical diagnostics, pharmacology and veterinary medicine. It is also used in the treatment of bacterial and viral infections, skin and eye diseases, periodontitis, leukemia and cancer (Lesnierowsk, 2009; Benkerroum, $2008[31,32])$. 


\subsection{Proteose Peptone Component $3\left(\mathrm{PP}_{3}\right)$}

These are those proteins that are left in solution after the milk is heated at high temperature followed by its acidification up to $\mathrm{pH} 4.7$.

The proteose peptone 3 component is found only in whey excluding from the human source. It is produced during the fermentation of fat-free bovine milk and enhances the production of monoclonal antibodies by human hybridoma cells (Krissansen, 2007 [33]).

\section{Therapeutic Properties of Milk Whey}

\subsection{Antimicrobial}

Milk whey—also known as cheese whey (Lactoserum)—contains several unique components that possess some important antimicrobial and antiviral properties. These are immunoglobulins, lactoferrin, lactoperoxidase, glycomacropeptide and sphingolopids. All these compounds are able to survive after their passage through stomach and small intestine and exert their biological effects in the large intestine. The important whey components that provide antimicrobial action in the intestinal tract are the immunoglobulins like IgG, IgM and IgA. IgG binds to toxin produced by Clostridium difficile, thereby reducing diarrhoea, dehydration and muscle aches. GMP inhibits binding of cholera toxin to receptors in the intestinal tract.

Lactoferrin, an iron binding protein present in milk whey, possesses antibacterial properties. It sequesters iron from bacteria (Troost et al., 2001 [34]). Since pathogens in particular have high iron requirements for metabolism and growth, this property of lactoferrin makes it broadly antimicrobial in nature. Lactobacilli can utilize lactoferrin-bound iron, thus allowing lactoferrin to both inhibit pathogenic bacteria and support the growth of lactobacilli.

Moreover, lactoferrin possess important antiviral activity as.it directly interacts with selected viral pathogens, inhibits virus replication and their ability to attach to colonic epithelial cells. Viral inhibition also results through immune modulation benefits of lactoferrin.

Another whey-derived important protein component is lactoperoxidase (Lp) with potent antimicrobial properties. It catalyzes the oxidation of thiocyanate into hypothiocynate ion, which is a strong oxidizing agent. Hypothiocynate ions disrupts bacterial cell membranes. This "Lactoperoxidasesystem" is therefore used in a milk-preservation system. Whey-derived phospholipids such as sphingolipids are metabolized in the gastrointestinal (GI) tract and produce sphingosine and lysosphingomyelin. These compounds possess powerful bactericidal agents in vitro.

Cheese whey (Lactoserum) was used as an inexpensive medium to produce bacteriocin by Bacillus sp. P11 (Leães et al., 2010 [35]). Bacteriocins are antimicrobial peptides produced by lactic acid bacteria group.

The lactoferrin, $\alpha$-Lactalbumin and $\beta$-Lactglobulin were also studied for their antagonistic activity against Human Immunodeficiency Virus type-1 (HIV-1) (Chatterton et al., 2006 [36]). In particular, $\beta$-Lactglobulin is potential agent for preventing the transmission of genital herpes virus infections and the spread of HIV. The lactoferrin and lactoferricin exhibit inhibitory activity against a broad range of microorganisms including Gram-negativeand, Gram-positive bacteria, yeast, fungi and parasitic protozoa (Takakura et al., 2003 [37]). They also inhibit the growth of food-borne pathogens such as E. coli and Listeria monocytogenes (Floris et al., 2003 [38]).

The Lf exhibits antiviral property against HIV, Human Cytomegalovirus (HCMV), herpes viruses, Human Papilloma Virus (HPV), alpha-virus and hepatitis C, B and G viruses. Overall, whey proteins activate immune cell and/or prevent infection. They show promise to help combat rota-viral diarrhea, which is a common infection in children (Wolber et al., 2005 [39]). The natural antimicrobial action of Lp is used in a range of oral healthcare products and in the prevention and treatment of xerostimia (dry mouth). Whey protein concentrate supplementation can thus decrease the occurrence of associated co-infections (Solak and Akin, 2012 [40]). 


\subsection{Anti-Cancerous}

Some cheese whey components possess anticancer properties. The sulphur-containing amino-acids including cysteine and methionine, are found in good amounts in whey protein. Cysteine and methionine are utilized in glutathione synthesis. Glutathione is a substrate for two classes of enzymes that catalyze detoxification compounds and bind mutagens and carcinogens, thus facilitating their elimination from the body. The ability of lactoferrinto bind iron is another added advantage in the prevention of colon cancer. They induce apoptosis in tumour cells and so are useful adjunct in colon cancer therapy.

Sphingomyelin, one of the most abundant whey-derived sphingolipids, have potential to inhibit colon cancer. Sphingomyelins also regulate growth factor receptors, such as the transforming growth factor beta family (TGF- $\beta$ ).

TGF- $\beta$ s are a multifunctional family of growth factors that regulate cell growth in normal and tumour cells by suppressing proliferation, inducing differentiation and apoptosis. TGF- $\beta$ passes out unaffected through the stomach and maintains bioactivity in colon by withstanding enzymatic proteolysis.

Several scientific studies, based on experiments on animal experiments have shown the therapeutic effect of bovine lactoferrin (BLF) in treating distinct types of cancer (Gill \& Cross, 2000 [41]), including colon cancer (Masuda et al., 2000 [42]). Besides this, the iron-binding capacity of bovine lactoferrin is responsible for its anticancer activity. The proposed mechanisms are that free iron act as a mutagenic promoter, by inducing oxidative damage to the nucleic acid structure; hence, when bovine lactoferrin binds iron in tissues, it reduces the risk of oxidant-induced carcinomas and colon adenocarcinomas. Studies are also available that pertain to such other cancers as lung, bladder, tongue and oesophagus, and which convey similar results (Masuda et al., 2000; Tanaka et al., 2000 [42,43]).

\subsection{Immune-Enhancer}

IgGs, Lp and Lf concentrated from whey participates in host immunity. IgGs binds with bacterial toxins and lowers the bacterial load in the large bowel. Dietary Lp and Lf plays a vital role in host immunity through their antibacterial action on pathogenic microorganisms. Thus, supplementing diets with whey-derived adjuncts shifts the balance of intestinal microflora and aids in immune enhancement. Calcium, by virtue of its probiotic activity and influence on macrophages, neutrophils and other white blood cell (WBC) subtypes are also classified as immune-modifying minerals.

Lf provides immune modulation as it is a natural component of the human immune system and is found in the body's mucous substances including saliva.

TGFs are abundant in milk (1-2 mg/L) and colostrum (20-40 mg/L) and serve a major role in GI integrity of newborn animals.

TGF-beta2 resides locally near the top of the intestinal villi, and inhibits the proliferation and signaling neutrophils as a part of innate host immunity.

Bovine lactoferrin upon stimulation of the immune system increases macrophage activity, causes induction of inflammatory cytokines, including IL-8, TNF-a and nitric oxide, stimulates proliferation of lymphocytes, and activates monocytes, natural killer (NK) cells and neutrophils (Gahr et al., 1991 [44]).

\subsection{Prebiotic Properties}

There are some whey-derived carbohydrate components that possess prebiotic activity. Lactose support LAB (such as Bifidobacteria \& Lactobacilli). Stallic acids (type of oligosaccharides that are commonly found in whey), are typically attached to proteins that have been shown to possess prebiotic properties. Besides, three other non-carbohydrate prebiotics from whey are a protein called glycomacropeptide (GMP) that is derived from the partial enzymatic breakdown of kappa-casein during cheese production that supports the growth of bifidobacteria; second is lactoferrin (Lf), which supports the growth of bifidobacteria and lactobacilli and third component with prebiotic potential 
is mineral, calcium in form of calcium phosphate. It selectively stimulates the growth of intestinal lactobacilli and decreases the severity of Salmonella infections in rats (Kassem et al., 2015 [45]).

\subsection{Anti-Inflammatory Properties}

The role of whey proteins on hypertension is due to its effect on inflammation and Renin-Angiotensin System (RAS). The Angiotensin-Converting Enzyme (ACE) inhibitors possess anti-inflammatory properties (Sousa et al., 2012 [46]). In a study it was found that the consumption of whey proteins depleted the plasma levels of pro-inflammatory cytokines (IL-1 beta: 59\% and IL-6: 29\%) as compared to the consumption of same amount of casein. Thus, reduction of pro-inflammatory cytokines can also be associated with weight loss after consumption of whey proteins and its amino acids (Luhovyy et al., 2007 [47]).

\subsection{Cardiovascular and Related Diseases}

Cardiovascular disease (CVD) is associated with number of factors such as age, genetic constitution, obesity, sedentary lifestyle and alcohol intake and quality of dietary fat. Milk contains more than 12 different types of fat, including sphingolipids, free sterols, cholesterol and oleic acid. Several studies have shown that intake of milk and dairy products lower blood pressure and reduce the risk of hypertension (Groziak and Miller, 2000 [48]).

A study was undertaken to investigate the effect of fermented milk (Lactobacillus casei and Streptococcus thermophiles) supplement with an added whey protein concentrate on serum lipids and blood pressure on a group of 20 healthy adult males (Kawase et al., 2000 [49]). During the course of eight weeks, volunteers consumed $200 \mathrm{~mL}$ of fermented milk with whey protein concentrate or a placebo in the morning and evening. The placebo consisted of a non-fermented milk product without the addition of whey protein concentrate. After eight weeks, the fermented-milk group showed significantly higher High Density Lipoproteins (HDLs) and lower triglycerides and systolic blood pressure than did the placebo group.

In yet another study, the aim was to investigate the acute effects of dietary whey proteins on lipids, glucose and insulin, and resting energy expenditure in overweight and obese post-menopausal women, a population that is highly susceptible to cardiovascular disease. The findings suggested that a single dose of whey protein can decrease arterial exposure to smaller triglycerides-enriched lipoprotein particles compared to the glucose and casein meals in the postprandial period in overweight and obese, post-menopausal women (Pal et al., 2010 [50]).

\subsection{GastroIntestinal Health}

Whey proteins exert a therapeutic effect on the gastric mucosa. This effect is due to the presence of sulfhydryl group in aminoacid cysteine and its linkage with glutamic acid in the production of glutathione.

In a research by Rosaneli et al. [51], it was observed that when rats showed a $41 \%$ reduction in ulcerative lesions caused by ethanol ingestion when they were fed a whey protein concentrate, while a 73\% reduction rate was observed following repeat doses of whey (McGregor and Poppitt, 2013 [52]).

Whey proteins are absorbed faster in body than casein. The lower absorption rate of casein in its native micellar form is due to the low $\mathrm{pH}$ conditions in the stomach that cause casein clotting and delays gastric emptying (Dangin et al., 2001 [53]). Therefore, plasma amino acids are more rapidly elevated following whey proteins consumption; whereas changes in plasma amino acids are lower and more sustained following micellar casein consumption. Thus, processing of whey proteins or casein fractions through hydrolysis can markedly influence absorption and subsequent plasma amino acid profiles. 


\subsection{Physical Strength and Performance for Athletes}

Several studies have shown that whey proteins have tremendous nutraceutical potential for athletes. They are often referred to as 'gold standard' or 'fast protein' for their unique ability to provide nourishment to muscles. This is due to several factors such as their solubility, easily digestible, efficient absorption. They contain all the essential amino acids required in daily diet and have an ideal combination of amino acids to help to improve body composition and enhance athletic performance.

Whey protein is a rich source of branched chain amino acids that are important for athletes since they are metabolized directly into muscle tissue and repair and rebuild lean muscle tissue. Whey protein is an excellent source of leucine (an essential amino acid) that plays a key role in promoting muscle protein synthesis and muscle growth in athletes. It has been reported that whey protein isolate has approximately $50 \%$ more leucine than soy protein isolate. Whey protein increases the level of glutathione in the body and helps to maintain a healthy immune system (Gupta et al., 2012 [4]).

\subsection{Obesity Control}

Numerous studies have proved that whey proteins help in weight management and obesity control. The mechanism involved is through the influence of whey proteins on the hormones that controls appetite and hunger (Hall et al., 2003 [54]). Consumption of a high-protein diet has a greater satiety thereby reducing energy intake and subsequent adiposity. It has been found that whey proteins are even more effective than red meat in reducing weight gain and also increases insulin sensitivity of the body. The other proposed mode of action is that diet rich in $\alpha$-lactalbumin enhances the lipid oxidation and rapidly delivers amino acids for use during exercise, thereby decreasing adiposity (Bouthegourd et al., 2002 [55]). Calcium is also known to influence energy metabolism as it regulates adipocyte lipid metabolism and triglyceride storage. This has been experimentally supported by Zemel 2002 [56] who demonstrated a greater effect of dairy versus non-dairy sources of calcium for improving body composition.

\subsection{Protection against Human Immunodeficiency Virus (HIV)}

Research has shown that individuals infected with HIV exhibit glutathione deficiency. Supplementation of whey elevates the levels of glutathione (GSH) and helps in increasing the immune defense mechanism of the host.

A research was undertaken by Micke et al. [57] on 30 subjects infected with HIV. They were randomized and received a daily dose of $45 \mathrm{~g}$ whey proteins from one of two sources Protectamin ${ }^{\circledR}$ or Immunocal. These two products are commercially available and possess different amino acid profiles. The oral supplementation was given for two weeks. After two weeks, the Protectamin-supplemented group demonstrated significantly elevated glutathione levels while the Immunocal group had statistically non-significant elevations. These results clearly showed that high levels of glutathione supplementation provide protection against HIV.

\subsection{Diabetes}

Numerous studies have proved that whey proteins help to control the blood glucose levels and provide additional benefits for weight management. This is a main concern for type-2 diabetics (Shankar and Bansal, 2013 [58]). Whey proteins are thus high biological, high-quality and value protein suitable for diabetic patients. Ingestion of whey proteins leads to more rapid secretion of insulin than micellar casein (McGregor and Poppitt, 2013 [52]).

\subsection{Appetite Suppression}

It has been mentioned earlier that whey based beverages regulates body weight and helps in controlling obesity. This is due to some amino acids liberated from whey proteins during in vivo digestion that also stimulate the release of hormones including insulin. Its secretion directly affects 
food intake regulation by modifying glycemic response and suppressing appetite and, consequently reduces body weight... Some other hormones are also involved in appetite suppression either directly in the hypothalamus, such as ghrelin, or indirectly through the vagal nerve, such as cholecystokinin (CCK) and Peptide YY (PYY) (Jakubowicz and Froy, 2013 [59]). Glyco-macropeptide is a powerful stimulator of CCK, which is an appetite-suppressing hormone that plays essential roles related to gastrointestinal function; including the regulation of food intake. Further research is required to study the effects of GMP and CCK as an appetite suppressant (Walzem, 1999 [60]).

\subsection{Ageing}

Numerous studies have shown that whey protein based drinks play an important role in delaying the ageing process. During ageing, there is a continuous but slow degeneration of skeletal muscle mass (sarcopenia). In elderly population the skeletal muscle mass is completely impaired and inhibited. Whey proteins are a rich source of essential amino acids that contributes to its anabolic properties. There is an increase in availability of postprandial plasma amino acids that stimulates synthesis of muscle proteins (Pennings et al., 2011 [61]). Whey proteins contain glutathione that is an important antioxidant involved in the maintenance of functional and structural integrity of muscular tissue undergoing oxidative damage during exercise and aging.

\subsection{Wound Healing}

Wound healing involves the growth of new skin through the use of proteins and their amino acids. Healing process is delayed when there are inadequate amounts of protein or diets high in poor-quality proteins, such as gelatin are present. Whey proteins comprises of good quality proteins and are therefore often recommended by physicians after any surgery or burn therapy (Gupta et al., $2012[4])$.

\section{Therapeutic Applications of Fermented Whey}

The therapeutic potential and functional properties of milk whey can be improved through fermentation (Yang and Silva, 1995 [62]). During fermentation by probiotic bacteria, the percentage of essential and digestible amino acids increases to a marked level, thus making these fermented dairy products ideal nutritional supplements for diarrhea and other conditions (Hitchins and Mc Donough, 1989 [63]). Various compounds including flavouring compounds and acids are produced due to the metabolic activity of these microorganisms. This also increases their palatability and consumer acceptability as compared to non-fermented products. The organic acids produced during the fermentation possess great health benefits. These organic acids comprise of short-chain fatty acids such as acetic, citric and lactic acid produced during the fermentation of protein and carbohydrate components. The organic acids possess antimicrobial properties particularly against $E$. coli in the intestine. The organic acids helps to lower the $\mathrm{pH}$ of the intestine that helps in the secretion of bile juices, absorption of nutrients and also reduce the concentration of pathogenic microglora in the gut. The SCFA is used in the colon to promote water and electrolyte absorption for diarrhoea treatment (Desjeux, 2000 [64]).

In a study in rats it was also reported that dietary calcium, preferably as calcium phosphate, also selectively favours the growth of intestinal lactobacilli and decreases the severity of Salmonella infections (Bovee-Oudenhoven et al., 1999 [65]).

In a study, Lactobacillus acidophilus subsp. johnsonii (La1) has been shown to effectively suppress the growth of Helicobacter pylori in vitro. The results were confirmed by conducting a hydrogen breath test. The whey-drink based on L. acidophilus (johnsonii) culture was given to some volunteers and a marked decrease in test values was observed (Michetti, 1999 [66]). 


\section{Whey-Based Probiotic Products}

During recent years there has been great awareness about the consumption of dairy products amongst the consumers worldwide. Dairy products containing probiotic bacteria of selected strains preferably belonging from the group of Lactobacillus spp. and Bifidobacterium spp. are generally preferable. Fermented dairy products such as whey have a greater consumer appeal as they are nutritious, thirst-quenching, less acidic and low in calories. Since dairy products are highly perishable they are susceptible to microbial spoilage during storage. Nowadays, liquid whey is therefore concentrated by spray drying or by evaporation, ultrafiltration or reverse osmosis thereby increasing their shelf life.

Besides, these whey drinks are further fortified with the friendly probiotic bacteria for their health promoting properties, and provide unique texture and flavor to them. Some whey-based probiotic products available in the market are Yakult and Sofyl (manufactured by Yakult), Chamyto (by Nestlé), Activia, Actimel, Danito (by Danone), Vigor-Club (by Vigor) (Katz, 2001 [67]).

The most common method of producing whey drinks is to remove excess of whey during cheese manufacturing process. The liquid whey is then filtered, pasteurized and fermented with the desired probiotic strain. It has been commonly observed that sweet whey (prepared after coagulation with rennet) is tastier than acid whey. The whey obtained through this process is clearer and is thus not sedimented during long term storage. This is called deproteinised whey. Such whey drinks can also be easily carbonated similar to soft drinks due to their low viscosity. (Wilson and Temple, 2004 [68]).

In a study, when a whey based beverages fortified with probiotic culture of Lactobacillus acidophilus was administered to diarrheal children, positive results were reported (Goyal and Gandhi, 2008 [69]).

It is necessary that the whey based beverages should be fortified with only specific viable probiotic strain(s) in sufficient numbers and scientifically validated with appropriate labeling in order to ensure therapeutic results (Reid et al, 2006 [70]).

\section{Conclusions}

From the above discussion, it is imperative that milk whey possess tremendous therapeutic properties such as antimicrobial, anticancer, immune-enhancer, prebiotic property, anti-inflammatory, cardiovascular, gastro-intestinal health, physical strength, obesity control and weight-management, HIV, diabetes, appetite suppression, ageing, and wound healing. There are several whey-based probiotic products available in the market today that can serve as attractive health-promoting food supplements. Kefir, yogurts, frozen yogurts and desserts are all well-known examples.

Acknowledgments: The authors greatly acknowledge and thank respected Founder President Ashok K. Chauhan, and Atul Chauhan, Chancellor, Amity University UP, Noida, India, for their constant motivation, support and, research facilities.

Author Contributions: Charu Gupta has contributed towards data collection, drafting and compiling of the manuscript while Dhan Prakash has critically reviewed the manuscript for its accuracy and completeness.

Conflicts of Interest: The authors declare no conflict of interest.

\section{Appendix A}

Table A1. Nutrient content of cheese whey types (dry matter basis).

\begin{tabular}{lcc}
\hline Nutrient Content & Sweet Whey (\%) & Whey Permeate (\%) \\
\hline Total nitrogen $(\mathrm{TN})$ & 1.30 & 0.26 \\
Non-protein nitrogen (NPN) & 0.34 & 0.24 \\
Calcium & 0.058 & 0.055 \\
Phosphorus & 0.052 & 0.045 \\
Net energy lactation (Mcal/lb) & 0.90 & 0.85 \\
Total digestible energy (Mcal/lb) & 1.86 & 1.7 \\
\hline
\end{tabular}


Table A2. Whey Characteristics.

\begin{tabular}{lcc}
\hline Characteristics Chemical Composition & Sweet Whey & Whey Permeate \\
\hline Specific gravity (kg/L) & 1.025 & 1.030 \\
pH & 6.40 & 6.55 \\
Titrable acidity & 0.05 & 0.089 \\
Water (\%) & 91.95 & 94.45 \\
Dry matter (DM\%) & 8.05 & 5.55 \\
- Solid not fat (SNF\%) & 7.55 & 5.55 \\
- Fat (\%) & 0.50 & 0.00 \\
Crude protein (CP\%) & 1.10 & 0.25 \\
Soluble carbohydrates (\%) & 5.20 & 4.90 \\
Total ash (\%) & 0.52 & 0.50 \\
\hline
\end{tabular}

\section{References}

1. Yalcin, A.S. Emerging therapeutic potential of whey proteins and peptides. Curr. Pharm. Des. 2006, 12, 1637-1643. [CrossRef] [PubMed]

2. Sultan, S.; Huma, N.; Butt, M.S.; Aleem, M.; Abbas, M. Therapeutic potential of dairy bioactive peptides: A Contemporary Perspectives. Crit. Rev. Food Sci. Nutr. 2016. [CrossRef] [PubMed]

3. Rognvaldardottir, N. Icelandic Food and Cookery; Hippocrene Books: New York, NY, USA, 2001.

4. Gupta, C.; Prakash, D.; Garg, A.P.; Gupta, S. Whey Proteins: A novel source of Bioceuticals. Mid. East J. Sci. Res. 2012, 12, 365-375.

5. Yolken, R.H.; Losonsky, G.A.; Vonderfecht, S.; Leister, F.; Wee, S.B. Antibody to human rotavirus in cow's milk. N. Engl. J. Med. 1985, 312, 605-610. [CrossRef] [PubMed]

6. Le Maux, S.; Giblin, L.; Croguennec, T.; Bouhallab, S.; Brodkorb, A. $\beta$-Lactoglobulin as a molecular carrier of linoleate: Characterization and effects on intestinal epithelial cells in vitro. J. Agric. Food Chem. 2012, 60, 9476-9483. [CrossRef] [PubMed]

7. Mehraban, M.H.; Yousefi, R.; Taheri-Kafrani, A.; Panahi, F.; Khalafi-Nezhad, A. Binding study of novel anti-diabetic pyrimidine fused heterocycles to $\beta$-lactoglobulin as a carrier protein. Coll. Surf. B Biointerfaces 2013, 112, 374-379. [CrossRef] [PubMed]

8. Brück, W.M.; Gibson, G.R.; Brück, T.B. The effect of proteolysis on the induction of cell death by monomeric alpha-lactalbumin. Biochimie 2014, 97, 138-143. [CrossRef] [PubMed]

9. Ganjam, L.S.; Thornton, W.H.; Marshall, R.T.; MacDonald, R.S. Antiproliferative effects of yoghurt fractions obtained by membrane dialysis on cultured mammalian intestinal cells. J. Dairy Sci. 1997, 80, 2325-2339. [CrossRef]

10. Markus, C.R.; Olivier, B.; de Haan, E.H. Whey protein rich in a-lactalbumin increases the ratio of plasma tryptophan to the sum of the other large neutral amino acids and improves cognitive performance in stress-vulnerable subjects. Am. J. Clin. Nutr. 2002, 75, 1051-1056. [PubMed]

11. Huang, B.X.; Kim, H.; Dass, C. Probing three-dimensional structure of bovine serum albumin by chemical cross-linking and mass spectrometry. J. Am. Soc. Mass Spectrom. 2004, 15, 1237-1247. [CrossRef] [PubMed]

12. Laursen, I.; Briand, P.; Lykkesfeldt, A.E. Serum albumin as a modulator of the human breast cancer cell line MCF-7. Anticancer Res. 1990, 10, 343-352. [PubMed]

13. Choi, J.K.; Ho, J.; Curry, S.; Qin, D.; Bittman, R.; Hamilton, J.A. Interactions of very long chain saturated fatty acids with serum albumin. J. Lipid Res. 2002, 43, 1000-1010. [CrossRef] [PubMed]

14. Tong, L.M.; Sasaki, S.; McClements, D.J.; Decker, E.A. Mechanisms of the antioxidant activity of a high molecular weight fraction of whey. J. Agric. Food Chem. 2000, 48, 1473-1478. [CrossRef] [PubMed]

15. Pierce, A.; Colavizza, D.; Benaissa, M.; Maes, P.; Tartar, A.; Montreuil, J.; Spik, G. Molecular cloning and sequence analysis of bovine lactotransferrin. Eur. J. Biochem. 1991, 196, 177-184. [CrossRef] [PubMed]

16. Levay, P.F.; Viljoen, M. Lactoferrin: A general review. Haematologica 1995, 80, 252-267. [PubMed]

17. El-Loly, M.M.; Mahfouz, M.B. Lactoferrin in Relation to Biological Functions and Applications: A Review. Int. J. Dairy Sci. 2011, 6, 79-111. [CrossRef]

18. El-Loly, M.M. Identification and Quantification of Whey Immunoglobulins by Reversed Phase Chromatography. Int. J. Dairy Sci. 2007, 2, 268-274. 
19. Losso, J.N.; Dhar, J.; Kummer, A.; Li-Chan, E.; Nakai, S. Detection of antibody specificity of raw bovine and human milk to bacterial lipopolysaccharides using PCFIA. Food Agric. Immunol. 1993, 5, 231-239. [CrossRef]

20. Scammell, A.W. Production and uses of colostrum. Aust. J. Dairy Technol. 2001, 56, 74-82.

21. Garry, F.B.; Adams, R.; Cattell, M.B.; Dinsmore, R.P. Comparison of passive immunoglobulin transfer to dairy calves fed colostrum or commercially available colostral supplement products. JAVMA 1996, 208, 107-110. [PubMed]

22. Hilpert, H.; Brussow, H.; Mietens, C.; Sidoti, J.; Lerner, L.; Werchau, H. Use of bovine milk concentrate containing antibody to rotavirus to treat rotavirus gastroenteritis in infants. J. Infect. Dis. 1987, 156, 158-166. [CrossRef] [PubMed]

23. Korhonen, H.; Marnila, P.; Gill, H.S. Milk immunoglobulins and complement factors. Br. J. Nutr. 2000, 84, S75-S80. [CrossRef] [PubMed]

24. Lilius, E.M.; Marnila, P. The role of colostral antibodies in prevention of microbial infections. Curr. Opin. Infect. Dis. 2001, 14, 295-300. [CrossRef] [PubMed]

25. De Wit, J.N.; van Hooydonk, A.C.M. Structure, functions and applications of lactoperoxidase in natural antimicrobial systems. Neth. Milk Dairy J. 1996, 50, 227-244.

26. Reiter, B.; Perraudin, J.P. Lactoperoxidase, Biological Functions. In Peroxidases in Chemistry and Biology; Everse, J., Everse, K.E., Grisham, M.B., Eds.; CRC Press: Boca Raton, FL, USA, 1991; pp. 144-180.

27. Shin, K.; Wakabayashi, H.; Yamauchi, K.; Teraguchi, S.; Tamura, Y.; Kurokawa, M.; Shiraki, K. Effects of orally administered bovine lactoferrin and lactoperoxidase on influenza virus infection in mice. J. Med. Microbiol. 2005, 54, 717-723. [CrossRef] [PubMed]

28. Marshall, K. Therapeutic applications of whey protein. Altern. Med. Rev. 2004, 9, 136-156. [PubMed]

29. Gustafson, D.R.; McMahon, D.J.; Morrey, J.; Nan, R. Appetite is not influenced by a unique milk peptide: Caseinomacropeptide (CMP). Appetite 2001, 36, 157-163. [CrossRef] [PubMed]

30. Fox, P.F.; Kelly, A.L. Indigenous enzymes in milk: Overview and historical aspects-Part 2. Int. Dairy J. 2006, 16, 517-532. [CrossRef]

31. Lesnierowsk, G. New manners of physical-chemical modification of lysozyme. Nauka Przyr. Technol. 2009, 3, $1-18$.

32. Benkerroum, N. Antimicrobial activity of lysozyme with special relevance to milk. Afr. J. Biotechnol. 2008, 7, 4856-4867.

33. Krissansen, G.W. Emerging health properties of whey proteins and their clinical implications. J.Am. Coll. Nutr. 2007, 26, 713-723. [CrossRef]

34. Troost, F.J.; Steijns, J.; Saris, W.H.; Brummer, R.J. Gastric digestion of bovine lactoferrin in vivo in adults. J. Nutr. 2001, 131, 2101-2104. [PubMed]

35. Leães, F.L.; Vanin, N.G.; Sant'Anna, V.; Brandelli, A. Use of Byproducts of Food Industry for Production of Antimicrobial Activity by Bacillus sp. P11. Food Bioprocess Technol. 2010, 4, 822-828. [CrossRef]

36. Chatterton, D.E.W.; Smithers, G.; Roupas, P.; Brodkrob, A. Bioactivity of $\beta$-lactoglobulin and $\alpha$-lactalbumin-technological implications for processing. Int. Dairy J. 2006, 16, 1229-1240. [CrossRef]

37. Takakura, N.; Wakabayashi, H.; Ishibashi, H.; Teraguchi, S.; Tamura, Y.; Yamaguchi, H.; Abe, S. Oral lactoferrin treatment of experimental oral candidiasis in mice. Antimicrob. Agents Chemother. 2003, 47, 2619-2623. [CrossRef] [PubMed]

38. Floris, R.; Recio, I.; Berkhout, B.; Visser, S. Antibacterial and antiviral effects of milk proteins and derivatives thereof. Curr. Pharm. Des. 2003, 9, 1257-1275. [CrossRef]

39. Wolber, F.M.; Broomfield, A.M.; Fray, L.; Cross, M.L.; Dey, D. Supplemental dietary whey protein concentrate reduces rotavirus-induced disease symptoms in suckling mice. J. Nutr. 2005, 135, 1470-1474. [PubMed]

40. Solak, B.B.; Akin, N. Health benefits of whey protein: A review. J. Food Sci. Eng. 2012, 2, 129-137.

41. Gill, H.S.; Cross, M.L. Anticancer properties of bovine milk. Br. J. Nutr. 2000, 84, S161-S166. [CrossRef] [PubMed]

42. Masuda, C.; Wanibushi, H.; Sekine, K.; Yano, Y.; Otani, S.; Kishimoto, T.; Fukushima, S. Chemo-preventive effect of bovine lactoferrin on N-butyl-N-(4-hydroxybutyl)-nitrosamine-induced bladder carcinogenesis. Jpn. J. Cancer Res. 2000, 91, 582-588. [CrossRef] [PubMed]

43. Tanaka, T.; Kawabata, K.; Kohno, H.; Honjo, S.; Murakami, M.; Ota, T.; Tsuda, H. Chemo-preventive effect of bovine lactoferrin on 4-nitroquinoline 1-oxide induced tongue carcinogenesis in male F344 rats. Jpn. J. Cancer Res. 2000, 91, 25-33. [CrossRef] [PubMed] 
44. Gahr, M.; Speer, C.P.; Damerau, B.; Sawatzki, G. Influence of lactoferrin on the function of human polymorphonuclear leukocytes and monocytes. J. Leucoc. Biol. 1991, 49, 427-433.

45. Kassem, J.M. Future Challenges of Whey Proteins. Int. J. Dairy Sci. 2015, 10, 139-159. [CrossRef]

46. Sousa, G.T.D.; Lira, F.S.; Rosa, J.C.; de Oliveira, E.P.; Oyama, L.M.; Santos, R.V.; Pimente, G.D. Dietary whey protein lessens several risk factors for metabolic diseases: A review. Lipids Health Dis. 2012, 11, 67. [CrossRef] [PubMed]

47. Luhovyy, B.L.; Akhavan, T.; Anderson, G.H. Whey proteins in the regulation of food intake and satiety. J. Am. Coll. Nutr. 2007, 26, 704S-712S. [CrossRef] [PubMed]

48. Groziak, S.M.; Miller, G.D. Natural bioactive substances in milk and colostrum: effects on the arterial blood pressure system. Br. J. Nutr. 2000, 84, S119-S125. [CrossRef] [PubMed]

49. Kawase, M.; Hashimoto, H.; Hosoda, M.; Morita, H.; Hosono, A. Effect of administration of fermented milk containing whey protein concentrate to rats and healthy men on serum lipids and blood pressure. J. Dairy Sci. 2000, 83, 255-263. [CrossRef]

50. Pal, S.; Ellis, V.; Ho, S. Acute effects of whey protein isolate on cardiovascular risk factors in overweight, post-menopausal women. Atherosclerosis 2010, 212, 339-344. [CrossRef] [PubMed]

51. Rosaneli, C.F.; Bighetti, A.E.; Antonio, M.A.; Carvalho, J.E.; Sgarbieri, V.C. Efficacy of a Whey protein concentrate on the inhibition of stomach ulcerative Lesions caused by ethanol ingestion. J. Med. Food 2002, 5, 221-228. [CrossRef] [PubMed]

52. McGregor, R.A.; Poppitt, S.D. Milk protein for improved metabolic health: A review of the evidence. Nutr. Metab. 2013, 10, 46. [CrossRef] [PubMed]

53. Dangin, M.; Boirie, Y.; Garcia-Rodenas, C.; Gachon, P.; Fauquant, J.; Callier, P.; Ballèvre, O.; Beaufrère, B. The digestion rate of protein is an independent regulating factor of postprandial protein retention. Am. J. Physiol. Endocrinol. Metab. 2001, 280, E340-E348. [PubMed]

54. Hall, W.L.; Millward, D.J.; Long, S.J.; Morgan, L.M. Casein and whey exert different effects on plasma amino acid profiles, gastrointestinal hormone secretion and appetite. Br. J. Nutr. 2003, 89, 239-248. [CrossRef] [PubMed]

55. Bouthegourd, J.C.J.; Roseau, S.M.; Makarios-Lahham, L.; Leruyet, P.M.; Tome, D.G.; Even, P.C. A preexercise $\alpha$-lactalbumin-enriched whey protein meal preserves lipid oxidation and decreases adiposity in rats. Am. J. Physiol. Endocrinol. Metab. 2002, 283, E565-E572. [CrossRef] [PubMed]

56. Zemel, M.B. Mechanisms of dairy modulation of adiposity. J. Nutr. 2002, 133, 252-256.

57. Micke, P.; Beeh, K.M.; Buhl, R. Effects of long-term supplementation with whey proteins on plasma glutathione levels of HIV-infected patients. Eur. J. Nutr. 2002, 41, 12-18. [CrossRef] [PubMed]

58. Shankar, J.R.; Bansal, G.K. A study on health benefits of whey proteins. Int. J. Adv. Biotechnol. Res. 2013, 4, 15-19.

59. Jakubowicz, D.; Froy, O. Biochemical and metabolic mechanisms by which dietary whey protein may combat obesity and Type 2 diabetes. J. Nutr. Biochem. 2013, 24, 1-5. [CrossRef] [PubMed]

60. Walzem, R.L. Health Enhancing Properties of Whey Proteins and Whey Fractions; USA Dairy Export Council: Arlington, VA, USA, 1999.

61. Pennings, B.; Boirie, Y.; Senden, J.M.G.; Gijsen, A.P.; Kuipers, H.; van Loon, L.J.C. Whey protein stimulates postprandial muscle protein accretion more effectively than do casein and casein hydrolysate in older men. Am. J. Clin. Nutr. 2011, 93, 997-1005. [CrossRef] [PubMed]

62. Yang, S.T.; Silva, E.M. Novel products and new technologies for use of a familiar carbohydrate, milk lactose. J. Dairy Sci. 1995, 78, 2541-2562. [CrossRef]

63. Hitchins, A.D.; Mc Donough, F.E. Prophylactic and therapeutic aspects of fermented milk. Am. J. Clin. Nutr. 1989, 49, 675-684. [PubMed]

64. Desjeux, J.F. Can mal-absorbed carbohydrates be useful in the treatment of acute diarrhoea? J. Pediatr. Gastroenterol. Nutr. 2000, 31, 503-507. [CrossRef]

65. Bovee-Oudenhoven, I.M.; Wissink, M.L.; Wouters, J.T.; Van der Meer, R. Dietary calcium phosphate stimulates intestinal lactobacilli and decreases the severity of Salmonella infections. J. Nutr. 1999, 129, 607-612. [PubMed]

66. Michetti, P.; Dorta, G.; Wiesel, P.H.; Brassart, D.; Verdu, E.; Herranz, M.; Felley, C.; Porta, N.; Rouvet, M.; Blum, A.L.; et al. Effect of whey based culture supernatant of Lactobacillus acidophilus (johnsonii) LA1 on the Helicobacter pylori infection in human. Digestion 1999, 60, 203-209. [CrossRef] [PubMed]

67. Katz, F. Active cultures add function to yogurt and other foods. Food Technol. 2001, 55, 46-49. 
68. Wilson, T.; Temple, N.J. Beverages in Nutrition and Health; Humana Press: New York, NY, USA, 2004; p. 427, ISBN 1-59259-415-8.

69. Goyal, N.; Gandhi, D.N. Whey, a Carrier of Probiotics against Diarrhoea. Available online: http://www. dairyscience.info/probiotics/110-whey-probiotics.html?showall=1 (accessed on 17 May 2011).

70. Reid, G.; Kim, S.O.; Kohler, G.A. Selecting, testing and understanding probiotic microorganisms. FEMS Immunol. Med. Microbiol. 2006, 46, 149-157. [CrossRef] [PubMed] 